\title{
Variations in the Inter-lobar Fissures of Lungs Obtained from Cadavers of South Indian Origin
}

\author{
Variaciones en las Fisuras Pulmonares Interlobulares \\ de Cadáveres del Sur de la India
}

\author{
Suja Mary Jacob* \& Minnie Pillay**
}

\begin{abstract}
JACOB, S. M. \& PILLAY, M. Variations in the inter-lobar fissures of lungs obtained from cadavers of South Indian origin. Int. J. Morphol., 31(2):497-499, 2013.

SUMMARY: The proposed aim of the study was to elucidate the variations of the lung fissures and to correlate their importance in clinics. The study was conducted on 48 lung specimens, 30 right and 18 left, obtained from the cadavers of South Indian origin. Among the right-sided lungs, 2 specimens showed absence of horizontal fissure, and the remaining 25 showed incomplete horizontal fissure. Oblique fissure was incomplete in 15 lungs and one lung showed absence of oblique fissure. An accessory fissure was observed in 4 lungs. Among the left sided lungs, the oblique fissure was incomplete in 7 lungs. The presence of an accessory fissure was found in 5 lungs. With the development of radiological and endoscopic techniques and the advancement of pulmonary surgery, the knowledge of morphological variations of lung fissures is of utmost importance to clinicians to correctly locate the bronchopulmonary segment during pulmonary lobectomy, and for radiologists to correctly interpret X-rays and CT scans.
\end{abstract}

KEY WORDS: Oblique fissure; Horizontal fissure; Accessory fissure.

\section{INTRODUCTION}

Generally, human lungs are divided into lobes by fissures. The right lung is divided into upper and middle lobes by the horizontal fissure and the lower lobe separated from the middle lobe by the oblique fissure. The left lung is divided only by a single fissure, that is the oblique fissure, into upper and lower lobes. The fissures facilitate the movement of the lobes in relation to one another, which accommodates the greater distention and movement of the lower lobes during respiration. Thus, they help in a more uniform expansion of the whole lung (Rosse \& Gaddum-Rosse, 1997). Their position can be used as reliable landmarks in specifying lesions within the thorax in general and within the lungs in particular (Kent \& Blades, 1942).

Mostly these inter-lobar fissures are complete reaching up to the hilum of the lung and are lined by the pleura. But in some cases lungs are seen with incomplete inter-lobar fissures or even their absence where the lobes are either partially or completely fused with each other. Some lungs even show the presence of accessory fissures that are normally obliterated.

Such anatomical variations of the inter-lobar fissures of the lung are not uncommon and awareness about these variations is important for clinicians to successfully perform pulmonary lobectomies, and for radiologists to correctly interpret X-rays and CT scans. Hence an attempt has been made to study the morphology of lung fissures from specimens obtained from cadavers of South Indian origin.

\section{MATERIAL AND METHOD}

The study was conducted on 48 lung specimens, 30 right and 18 left, obtained from the cadavers of South Indian origin. These were examined carefully for the presence of any variant fissure such as an accessory fissure, incomplete horizontal and oblique fissures and also for the absence of any of the main fissures (horizontal and oblique).

\section{RESULTS}

In right lungs, the horizontal fissure was absent in 2 lungs $(6.6 \%)$ and incomplete horizontal fissure was found in 25 lungs (83.4\%). Oblique fissure was incomplete in 15 lungs $(50 \%)$. One lung showed absence of oblique fissure (3.4\%). An accessory fissure was observed in 4 lungs (13.3\%). 
In left lungs, the oblique fissure was incomplete in 7 lungs $(38.9 \%)$. The presence of an accessory fissure was found in 5 lungs $(27.7 \%)$.

\section{DISCUSSION}

During lung development, a part of the lung parenchyma developing from the lobar bronchi is separated from each other by mesoderm. This mesoderm forms the pleura, which lines the surface of each lobe separately, thus giving rise to fissures. Many of these fissures get obliterated, leaving the main fissures in their complete form throughout adult life (Singh \& Pal, 2001). Based on this, a human being has a right lung and a left lung, the right lung having two complete fissures with corresponding three lobes, while the left lung having only one complete fissure with corresponding two lobes. However, findings from live subjects (through CT scans) and specimens dissected from cadavers have frequently shown varying percentage of incomplete fissures, both oblique and horizontal, and also the presence of accessory fissures. In some, absence of the main fissures was also observed.

On the basis of CT scans, Otsuji et al. (1993) made an analysis of both lungs in 154 patients, including seven cadavers, and came to the conclusion that the frequency of the incomplete inter-lobar fissure was high in right sided lungs (83.1\%), when compared to the left lungs (50\%). In the present study, among the 48 lung specimens, it was found that the frequency of the incomplete inter-lobar fissure was high in right-sided lungs (83.3\%), when compared to the left sided lungs (38.8\%).

Medlar (1947) in his examination of 1200 pairs of lungs found incomplete oblique fissure in $10.6 \%$ of the left sided lungs and $25.6 \%$ of the right-sided lungs, and incomplete horizontal fissure in $17.1 \%$ of the right-sided lungs. Oblique fissure was absent in $7.3 \%$ of the left-sided and $4.8 \%$ of the right-sided lungs; horizontal fissure was absent in $45.2 \%$ of the right-sided lungs. Another study reported by Meenakshi et al. (2004), from among the 30 right-sided lungs, $16.6 \%$ showed absence of the horizontal fissure, while $63.3 \%$ had incomplete horizontal fissure. Oblique fissure was incomplete in $36.6 \%$ of the right-sided lungs. Absence of the oblique fissure was not reported. From among the left sided ones, $46.6 \%$ of them showed incomplete oblique fissure. Absence of this fissure was also not reported.

When compared with the studies of both Medlar and Meenakshi et al., nearly similar incidence of variations was observed in the present study, except in the case of the horizontal fissure of the right sided lungs, where a higher incidence of variation was seen in the incompleteness of the horizontal fissure (Fig. 1), which is comparatively similar with that of the study done by Meenakshi et al., but drastically different from that of Medlar's, where a higher incidence of variation was seen in the absence of the horizontal fissure (Table I). Similarly, in a study done by Berkmen et al. (1989), where he investigated CT sections of 40 patients, the frequency of incomplete horizontal fissure of the right-sided lungs was high (72\%), while absence of the horizontal fissure accounted for $20 \%$ of the total rightsided lungs.

Concerning the oblique fissure of right and left lungs, the present study reported higher incidence of incomplete oblique fissure in the right-sided lungs (50\%) (Fig. 2). Only $38.8 \%$ of the left sided lungs showed this anomaly. This is similar to a study done by Glazer et al. (1991), which reported an incomplete oblique fissure in the right lung in 32 cases $(64 \%)$, and in the left lung in 26 cases (52\%).

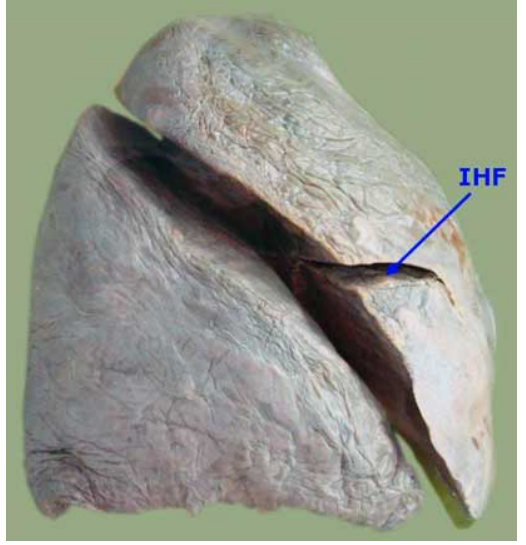

Fig. 1. Right lung showing incomplete horizontal fissure. IHF - Incomplete Horizontal Fissure.

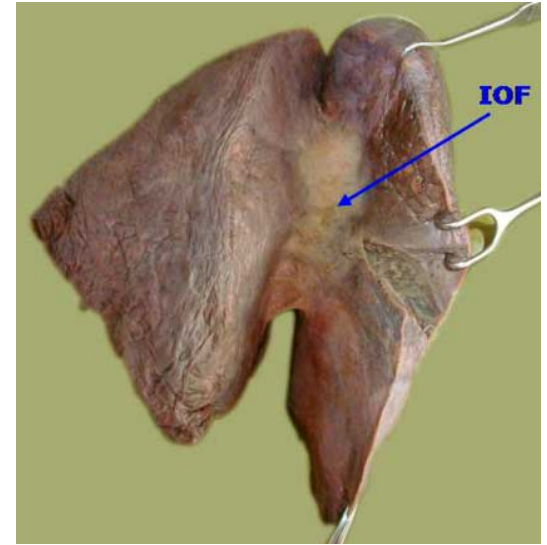

Fig. 2. Right lung showing incomplete oblique fissure. IOF - Incomplete Oblique Fissure.

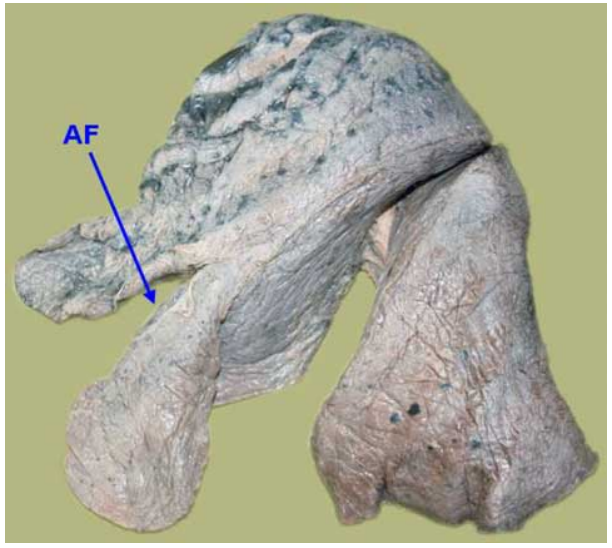

Fig. 3. The upper lobe of the left lung divided into two lobes by an accessory fissure. AF Accessory Fissure. 
Table I. Variations in the pattern of fissures of lungs as observed by different authors.

\begin{tabular}{llccc}
\hline Category & $\begin{array}{c}\text { Medlar } \\
(\mathbf{1 9 4 7 )}\end{array}$ & $\begin{array}{c}\text { Meenakshi } \\
\text { et al. (2004) }\end{array}$ & $\begin{array}{c}\text { Present } \\
\text { study }\end{array}$ \\
\hline Right & Horizontal & & & \\
lung & Absent & 45.2 & 16.6 & 6.6 \\
& Incomplete & 17.1 & 63.3 & 83.4 \\
& Obliqu e & & & \\
& Absent & 4.8 & nil & 3.4 \\
& Incomplete & 25.6 & 36.6 & 50 \\
Left & Oblique & & & \\
lung & Absent & 7.3 & nil & nil \\
& Incomplete & 10.6 & 46.6 & 38.9 \\
\hline
\end{tabular}

Incomplete development of the lung leads to incomplete formation of the fissures or causes their absence. In both the cases parenchymal fusion is seen. When part of the fissure is absent, it is always toward the mediastinal side of the fissure. Incomplete fissure may lead to the spread of disease and collateral air drift (Hayashi et al., 2001). It may alter the usual patterns of collapse seen in patients with endobronchial lesions and may also give rise to atypical type of pleural effusion (Meenakshi et al.). Familiarity with the appearance and implications of incomplete fissure is important for planning of lobar resection because there is a higher prevalence of air leak in lobar fusion (Hayashi et al.).

Another type of variation seen in lungs is the presence of accessory fissures. Accessory fissures of lungs usually occur at the boundaries between bronchopulmonary segments. Anatomically, an accessory fissure is a cleft of varying depth lined by visceral pleura (Godwin \& Tarver, 1985). Accessory fissures could be the result of non-obliteration of spaces, which are normally obliterated (Meenakshi et al.). In this study, 4 accessory fissures were seen in the right-sided lungs (13.3\%), and 5 in the left sided lungs (27.7\%) (Fig. 3). An accessory fissure acts as a barrier to infection spread, creating a sharply marginated pneumonia, which can normally be interpreted as atelectasis or consolidation (Godwin \& Tarver). From a radiological point of view, an accessory fissure is important as it can be mistaken for a lung lesion (Aldur et al., 1997).

JACOB, S. M. \& PILLAY, M. Variaciones en las fisuras pulmonares interlobulares de cadáveres del sur de la India. Int. J. Morphol., 31(2):497499, 2013.

RESUMEN: El objetivo fue determinar las variaciones de las fisuras del pulmón y correlacionarlas con su importancia clínica. Se utilizaron 48 muestras de pulmón, 30 del lado derecho y 18 del izquierdo, obtenidos de cadáveres de origen del Sur de la India. Entre los pulmones, en el lado derecho, dos mostraron ausencia de la fisura horizontal, y 25 mostraron una fisura horizontal incompleta. La fisura oblicua fue incompleta en 15 pulmones y en 1 pulmón estuvo ausente. Se observó una fisura accesoria en 4 pulmones. Entre los pulmones del lado izquierdo, la fisura oblicua estuvo incompleta en 7 casos. La presencia de una fisura accesoria se observó en 5 casos. Con el desarrollo de técnicas radiológicas, endoscópicas y el avance de la cirugía pulmonar, el conocimiento de las variaciones morfológicas de las fisuras de pulmón es de importancia para los médicos, permitiendo localizar correctamente el segmento broncopulmonar durante la lobectomía, y para los radiólogos para interpretar correctamente las radiografías y las Tomografías Computarizadas.

PALABRAS CLAVE: Fisura oblicua; Fisura horizontal; Fisuras accesorias.

\section{REFERENCES}

Aldur, M. M.; Denk, C. C.; Celik, H. H. \& Tasçioglu, A. B. An accessory fissure in the lower lobe of the right lung. Morphologie, 81(252):57, 1997.

Berkmen, Y. M.; Auh Y. H.; Davis S. D. \& Kazam E. Anatomy of the minor fissure: evaluation with thin-section CT. Radiology, 170(3 Pt. 1):647-51, 1989.

Glazer, H. S.; Anderson, D. J.; DiCroce, J. J.; Solomon, S. L.; Wilson, B. S.; Molina, P. L.; et al. Anatomy of the major fissure: evaluation with standard and thin-section CT. Radiology, 180(3):839-44, 1991.

Godwin, J. D. \& Tarver, R. D. Accessory fissures of the lung. AJR Am. J. Roentgenol., 144(1):39-47, 1985.

Hayashi, K.; Aziz, A.; Ashizawa, K.; Hayashi, H.; Nagaoki, K. \& Otsuji, $\mathrm{H}$. Radiographic and $\mathrm{CT}$ appearances of the major fissures. Radiographics, 21(4):861-74, 2001.

Kent, E. M. \& Blades, B. The surgical anatomy of the pulmonary lobes. J. Thorac. Surg., 12:18-30, 1942.

Medlar, E. M. Variations in interlobar fissures. Am. J. Roentgenol. Radium. Ther, 57(6):723-5, 1947.

Meenakshi, S.; Manjunath, K. Y. \& Balasubramanyam, V. Morphological variations of the lung fissures and lobes. Indian J. Chest Dis. Allied Sci., 46(3):179-82, 2004.

Otsuji, H.; Uchida, H.; Maeda, M.; Iwasaki, S.; Yoshiya, K.; Hatakeyama, M.; et al. Incomplete interlobar fissures: bronchovascular analysis with CT. Radiology, 187(2):541-6, 1993.

Rosse, C. \& Gaddum-Rosse, P. Hollinshead's Textbook of Anatomy. $5^{\text {th }}$ ed. Philadelphia, Lippincott-Raven, 1997.

Singh, I. \& Pal, G. P. Human Embryology. $7^{\text {th }}$ ed. New Delhi, Macmillan India Limited, 2001.

\section{Correspondence to:}

Ms. Suja Mary Jacob

Department of Anatomy

Amrita School of Medicine

Amrita Institute of Medical Sciences and Research Centre

Kochi- 682026

Kerala - INDIA

Email: smarjac85@gmail.com

Received: $14-08-2012$

Accepted: 13-01-2013 